\title{
Effect of humic acid and inorganic fertilizers on productivity, profitability, nutrient uptake and soil fertility in brinjal (Solanum melongena L.) var. KKM1 in Alfisol of Tamil Nadu
}

\section{PARAMASIVAN, V. ARUNKUMAR AND T. PRABHU}

Received : 04.08.2015; Revised : 03.10.2015; Accepted : 17.10.2015

MEMBERS OF RESEARCH FORUM:

Corresponding author : M. PARAMASIVAN, Department of Soil Science and Agricultural Chemistry, Agricultural College and Research Institute, Tamil Nadu Agricultural University, Killikulam, Vallanad, THOOTHUKUDI (T.N.) INDIA Email:paramusoil@gmail.com

\section{Co-authors :}

V. ARUN KUMAR AND T. PRABHU,

Department of Soil Science and Agricultural Chemistry, Agricultural College and Research Institute, Tamil Nadu Agricultural University, Killikulam, Vallanad, THOOTHUKUDI (T.N.) INDIA

\section{Summary}

A three year field experiment was conducted during September - March of 2010-2011 to 20122013 at Agricultural College and Research Institute, Killikulam to study the influence of humic acid with graded levels of inorganic fertilizers on productivity, nutrient uptake, economic and soil fertility of brinjal var KKM1. The experiment was carried out in Randomized Block Design replicated thrice with 11 treatments. Humic acid was applied through both in soil and foliar spray with 75 per cent $R D F\left(\mathrm{~N}_{75} \mathrm{P}_{37.5} \mathrm{~K}_{22.5}\right)$. Application of 75 per cent $R D F\left(\mathrm{~N}_{75} \mathrm{P}_{37.5} \mathrm{~K}_{22.5}\right)+10$ $\mathrm{kg} \mathrm{HA}(\mathrm{SA})+0.2$ per cent HA (FS) /ha produced significantly higher plant hight $(112.0 \mathrm{~cm})$, days to 50 per cent flowering (56.4), number of branches/plant (9.4), number of fruits /plant (25.3), single fruit weight ( $69.9 \mathrm{~g})$, fruit yield (33.4 t/ha), total dry matter production $(10.08 \mathrm{t} /$ ha), net return (Rs. 1,33,131 / ha) and B:C ratio (4.29), N, P and K (143.1, 33.3 and $148.6 \mathrm{~kg} / \mathrm{ha}$, respectively) uptake compared to control. However, 75 per cent RDF $\left(\mathrm{N}_{75} \mathrm{P}_{37.5} \mathrm{~K}_{22.5}\right)+10 \mathrm{~kg}$ HA (SA) + 0.1 per cent HA (FS) /ha had higher plant height, number of branches, days to 50 per cent flowering, number of fruits per plant, single fruit weight, fruit yield, total dry matter production, net return, B:C ratio, N,P and K uptake. Significant built up of organic carbon $(0.92 \%)$, available $\mathrm{N}(291.5 \mathrm{~kg} / \mathrm{ha})$, available $\mathrm{P}(25.4 \mathrm{~kg} / \mathrm{ha})$ and available $\mathrm{K}(293.7 \mathrm{~kg} / \mathrm{ha})$ was registered with 75 per cent RDF + $10 \mathrm{~kg} \mathrm{HA}(\mathrm{SA})+0.2$ per cent $\mathrm{HA}(\mathrm{FS}) /$ ha. The maximum balance of $\mathrm{N}, \mathrm{P}$ and $\mathrm{K}(25.5,8.6$ and $25.2 \mathrm{~kg} / \mathrm{ha}$, respectively) were recorded under the treatment with application of 75 per cent RDF $+10 \mathrm{~kg} \mathrm{HA}(\mathrm{SA})+0.2$ per cent HA (FS) /ha.

Key words : Alfisol, Available nutrients, Brinjal fruit yield, Humic acid, Nutrient content and uptake

How to cite this article : Paramasivan, M., Arunkumar, V. and Prabhu, T. (2015). Effect of humic acid and inorganic fertilizers on productivity, profitability, nutrient uptake and soil fertility in brinjal (Solanum melongena L.) var. KKM1 in Alfisol of Tamil Nadu. Asian J. Soil Sci., 10(2) : 185-190. 